\title{
Personal Qualities of M.S. Gorbachev and B.N. Yeltsin in Language Consciousness of Humanities Students
}

\section{Личные качества М.С. Горбачева и Б.Р. Ельцина в сознании студентов-гуманитариев}

\section{Irina Bubnova}

Dr. Sc. in Philology (Dr. habil.),

Professor

\section{Ирина Бубъова}

доктор филологических наук, профессор

E-mail: bubnovaia@mgpu.ru

https://orcid.org/0000-0002-1024-600X

Elena Tokareva

$\mathrm{Ph}$. D. in History,

Associate Professor

\section{Елена Токарева}

кандидат исторических наук, доцент

E-mail: TokarevaE@mgpu.ru

https://orcid.org/0000-0003-3551-2375

Moscow City University

4, Vtoroy Selskohoziajstvenny

proezd, Moscow, 29226
Государственное автономное образовательное учреждение высшего образования города Москвы "Московский городской педагогический университет"

$\triangle$ 2-й Сельскохозяйственный проезд, 4, Москва, 129226

Original manuscript received March 12, 2021

Revised manuscript accepted September 27, 2021

\section{ABSTRACT}

Objectives. The study aims at identifying and describing a fragment of the linguistic consciousness of humanitarian students, reflecting their ideas about the personal qualities of M.S. Gorbachev and B.N. Yeltsin. The additional tasks are: (1) to compare 
the characteristics identified experimentally with the linguistic characteristics of these personalities in the official mass media; (2) to analyze the role of media discourse in the formation of images of the politicians under study.

Material and Methods. The method of unipolar personal semantic differential is used. The process of the results included the identification of group universal assessments, their qualitative analysis, comparison and qualitative analysis of the similarities and differences of the universal evaluations of the stimuli studied. Media texts published for the 90th anniversary of Gorbachev and the 90th anniversary of Yeltsin, selected by the method of random (serial) sampling, were analyzed qualitatively.

Results. Group semantic universals reflecting students' perceptions of the politicians studied are poor in content. The most striking characteristic of Gorbachev are selfishness and deceitfulness, unlike Yeltsin he is thought to be hardworking and calm. A distinctive feature of Yeltsin is ambition. Both leaders appear as free in their behavior, the difference lies in the fact that Gorbachev is considered experienced, but devoid of tact and flexibility, Yeltsin lacks creativity, wit and malevolence. Both combine such traits as sociability, activity and intelligence. The experiment does not record the qualities that are emphasized in mass media - kindness and care for the good of the country.

Conclusions. The ideas of students about the personal qualities of Gorbachev and Yeltsin are rather vague, "kaleidoscopic" in nature. The group assessment of the personal characteristics of these politicians does not coincide with the interpretation offered by various mass media. Mass media today do not contribute to the development of a view of the history shared by a significant part of society, which, in turn, leads to the conservation of socio-political contradictions in society. Moreover, modern media, despite its advantageous position, now play rather a destructive role in creating a common view of the history of Russia and the quality of its recent leaders. The result may be a state of psychological conflict in society directly related to culture and the human self, with "identification confusion" (the term of E. Erickson) that has the function of a collective ego.

Key words: semantic differential, semantic universals, language consciousness, personal qualities, leaders, Russia, students, mass media.

\section{Introduction}

The study of methods of manipulating the consciousness of the mass audience used by the media and methods of forming a consensual public opinion on the most important issues concerning various aspects of public life and the activities of the state, have been in the principal focus of psycholinguistics since its formation as a separate sphere of scientific research (Leontiev, 1969, 1972, 1983). At present, the 
relevance of the issues of psycholinguistic analysis of social and mass communication in the aspect of their influence on mass consciousness is increasing every day, which is due to the combination of several factors.

Firstly, according to several foreign researchers, the leading position in the discourse of mass media today is occupied by modern neoliberalism - a political philosophy that determines the choice of topics for publications, the accents and even the systematic use of certain lexical and grammatical forms (Ming Liu, 2017). Moreover, modern "society of a show" created by the activities of mass media in the global information space allows them to assign educational and pedagogical functions gradually (Serre, 2016), constructing not only the "agenda", but also what and how should be said on the "designated" topic, therefore determining the interpretation and understanding of the world by an ordinary person (Harvey 2007: 22).

Another, but no less important reason determining the urgent need for such works is the structure of interaction between mass media and the audience, which has changed dramatically compared to the last century, and, above all, the complete transformation of social parameters of mass communication. On the one hand, the widest choice of media diversity, the emergence of various social media platforms has led to the customization of the society, creation of virtual communities, whose members can be either completely different in their demographic and social characteristics, or united on the basis of a factor that plays a key role for their integration (Blank \& Lutz, 2017). On the other hand, modern technologies, the digitalization of all spheres of life, the immersion of a person into the Internet reality almost from the moment of birth, accelerated the formation of the habit of subjects of social life to build all social practices in accordance with a new type of society (Kolomiets, 2017).

Taken together, these factors create radically different living conditions for the life of everyone compared to the last century. At first sight, the current situation leads to an unconditional increase in the influence of mass media. But such a statement cannot be considered indisputable: a constantly growing number of information channels, the opportunity to enter into a dispute with the authors, leave a comment, search for sources of information that differ in their preferences and, based on their analysis, make their own opinion, give a person freedom of choice and allow any consumer of media products to feel not 
Personal Qualities of M.S. Gorbachev and B.N. Yeltsin in Language...

a passive consumer but an active figure, a real co-creator of publications posted in print and social networks.

However, despite a significant number of works devoted to the role of mass media in modern social life (Gruzd \& Wellman, 2014, Gruzd et al., 2016, Gruzd, Jacobson \& Wellman, 2017), their contribution to the political polarization of society (Bail et al., 2018), the specifics of Russian mass media activities and the degree of its influence on the formation of the image of the world of young people, explicated in the content of their language consciousness - one of the main phenomena studied in the framework of psycholinguistics, haven't been deeply investigated yet. The study of this problem in a broad context is the main goal of our comprehensive research. The implementation of this goal was partially carried out during the ascertaining stage of an empirical study aimed at identifying the ideas of Russian students about personal qualities of the last President of the USSR and the first President of Russia.

\section{Methodology of empirical research}

In 2020-2021, in the light of the anniversaries of Mikhail Gorbachev and Boris Yeltsin, a large number of materials dedicated to them personally and evaluating their activities appeared in the Russian mass media, and all quality publications (both printed and online) in their publications (see, for example, "A man with his own opinion", "Remarks about Mikhail Gorbachev", 2021; VCIOM: the number of Russians who assess Gorbachev's activities negatively has decreased, 2021; The poll: Gorbachev thought about the benefit of the country, but made tactical errors, 2021; "The path from the tank to the coffin. The history of Boris Yeltsin in photos-for his 90th birthday", 2020) in some kind repeated the same statements, which indicates that mass media performs one of its main functions - the influence aimed at forming the consciousness of the masses.

Due to these circumstances, of particular interest is the perception of these leaders by the current generation of young people, whose knowledge and system of meaning-life orientations are not determined by direct personal experience but represent the phenomena that in the early twentieth century was designated as a stereotype constructed by the mass media (Bernays, 2010, Lippman, 1966). Nowadays within 
the framework of the discursive paradigm, the formation of which was influenced by the philosophy of postmodernity, such stereotype is considered as a sign expressed mainly through the text, which reflects the goals and interests of those who produced it. It is important that such a postmodern understanding of a sign representing the image of a historical event or a person in the mass consciousness fully corresponds to the interpretation of the media by G. McLuhan who showed that modern means of communication that can replace sequence with simultaneity, discard the illusion of perspective, become a message themselves, perceived by society as reality (McLuhan, 2018).

All the above fully corresponded to the general goal of our work - to determine the degree of influence of mass media discourses on mass consciousness. The subject of empirical research at this stage was the experimental identification and subsequent description of explicit ideas about the personal qualities of politicians who led Russia in its recent past in the language consciousness of Russian students. As complementary, we set the tasks of comparing the selected experimentally verbalized characteristics with the qualities that are in the focus of the mass media, and, respectively, analyzing and evaluating the role of political discourses in the formation of images of the studied personalities.

\section{The methodological basis of the study was:}

- the ideas that were developed in the cultural-historical theory of L.S. Vygotsky, in particular the idea about the leading role of the cultural development assistance, namely, "in the uptake of such methods of behavior which are based on the use of signs as a means for implementation of one or another psychological operations; $<\ldots>$ in the mastery of tool-using behaviors that humanity has created in the course of its historical development and what the language, letter, number system, etc. are" (Vygotsky, 2004: 192);

- basic principles of general psychological theory of activity (Leontiev, 2004);

- understanding of the psychological structure of the word's meaning in the theory of speech activity (Leontiev, 1969);

- entitlement of vocational specificity of human activity:

"professional differences also have an extension in the features of accepting objects of the world that are not directly professionally significant" (Artemyeva, 1999: 265). 


\section{Methods and procedure of empirical research}

The main method of research was the method of semantic differential, widely used in psycholinguistics, psychosemantics and psychology of subjective semantics, which allows to study the features of the use and functioning of meanings in any, and not only in speech, types of activity. In our work a unipolar personal semantic differential was used (Shmelev, Pokhilko \& Kozlovskaya-Telnova, 1988), which refers to specialized, subject-related ones that allow us to evaluate stimuli in a certain subject area (here - personal qualities of a politician). The list includes 64 named personality traits, estimated in numbers from 0 to 3 , which makes it possible to distinguish both the qualities that are absent (according to the data obtained) in the evaluated person, and those characteristics that he displays most vividly (Appendix 1).

Gradual processing of the results, which allows us to implement the tasks set in the study consistently, included:

- identification of group language universals of evaluation/ semantic universals - a list of "coordinates allocated for a given stimulus (rated on scales), equally evaluated by a significant majority of a homogeneous subject's groups" (Serkin, 2008: 259) using the following algorithm: (1) compilation of a group data matrix; (2) range selection of the span of the middle edges of the scale (in our case, the selection of $25.0 \%$ on the obtained scale); (3) calculation of the values of the indentation ranges; (4) the selection of descriptors, the average value of which is included in one of the indentation ranges, which cannot be recognized as random and is evidence of their significance in the minds of $75.0 \%$ of the participants of the experiment.

It should be highlighted that, despite the apparent simplicity of the method of semantic universals, in experimental science it is considered to be not only very productive, but also provides the construction of models that are "always broader, more informative and more valid than any factor or cluster model" (Serkin, 2008: 260) due to the fact that they are free "from the restrictions imposed by mathematical modeling procedures" (ibid.);

- qualitative analysis of the language universals of assessment;

- comparison and qualitative analysis of the similarities and differences of the obtained language universals for evaluating different stimuli. 
The stimulus words in the study were the names of Mikhail Gorbachev and Boris Yeltsin.

The choice of these stimulus words was determined by several factors. Firstly, in contrast to all top officials who ruled the Russian Empire and the USSR, the names of Mikhail Gorbachev and Boris Yeltsin are associated with not too distant past, whose witnesses transmit their knowledge and attitude to these personalities to the younger generation in various types of discourse, including mass media. Secondly, the linguistic tone of the coverage of their activities by the official mass media expresses the position taken by the state in relation to them and that period of history, which, to ensure a stable state of society, should become generally accepted.

Therefore, the position of mass media has been highlighted in many publications, but the degree of coincidence of the transmitted images with the externalized ideas about these political figures in the minds of the younger generation, as well as these ideas, have not been studied in the psycholinguistic aspect, which determines the scientific novelty of the work undertaken and the value of the results, that make it possible, on the one hand, to reveal the ideas about the qualities of certain personalities in the language consciousness of young people and, on the other hand, to draw preliminary conclusions about the effectiveness of discursive strategies and tactics of influence currently used by media workers.

\section{Sample}

In accordance with the goal set in the study, the respondents were university students studying in the areas of humanities - sociology, history, philology. The total number of participants is 41 people, including 17 boys, 24 girls; the average age is 20 years. All participants had completed secondary education in various regions of the Russian Federation, come from families belonging to the middle class. In other words, the group members are typical representatives of the younger generation, whose ideas about the past in a short period of time will determine the political situation in the country and the trends of its development.

The experiment was conducted in February-March 2021, the results were published in the Social Science Research Network (SSRN) and are accessible to the general public (Bubnova, 2021). 


\section{Compliance with ethical standards}

Before conducting the study, the respondents were notified about the purpose of the experiment, informed consent for voluntary participation in it was obtained from all members of the group.

The study was approved by the Committee on the Ethics of Scientific Research.

Compilation and conducting of the survey, as well as writing of this article, was not funded.

The authors confirm that they are not associated with any organization or company that has any financial or non-financial interest in the materials of the study under discussion.

\section{Results}

Primary data obtained during semantic scaling and entered in the matrix group results are presented in Table 1 and Table 2 .

In the result of mathematical processing of the data described in the algorithm above (min: $-0.78-1.04$; max: $-1.8-1.54 ; 25.0 \%=0.26$ ) a group semantic universal reflecting explicit verbal representations of students about personal qualities of Mikhail Gorbachev was constructed. It includes the following descriptors:

Missing qualities: constrained, flexible, tactful, subtle, pampered, beautiful, poetic.

The most distinctive personal qualities are calm, sociable, active, intelligent, open, simple, selfish, hardworking, experienced, optimistic, and quirky.

Group semantic universal of students' ideas about the personal qualities of B.N. Yeltsin (min: $-0.88-1.16$; $\max :-2.0-1.72 ; 25.0 \%=$ 0.28 ) based on the verbal characteristics selected from the presented list by the respondents is reflected in the following list:

Missing qualities: constrained, limited, subtle, inexperienced, witty, unfriendly, creative, pampered, insecure, poetic.

The most distinctive personal qualities are sociable, active, intelligent, simple, optimistic, ambitious.

A comparative analysis of the obtained semantic universals shows that in the respondents' perception existing in their language 
consciousness both leaders were free in their behavior and, as can be assumed, in decisions (Yeltsin did not have any complexes) and optimistic. The difference is that Gorbachev was deprived of tact and flexibility, and Yeltsin was deprived of creativity, wit, and malevolence. Moreover, if Gorbachev is considered an experienced politician, then among Yeltsin's personal qualities there is simply a lack of inexperience. It can be assumed that this circumstance explains the appearance of calmness directly related to the experience as a feature actualized in the process of verbal description of Gorbachev's personal qualities. This feature is absent in the semantic universal that reflects the group idea of Yeltsin's personality in the language consciousness of the studied group. It is symptomatic, in our opinion, that in the image of the latter existing in the language consciousness of students there is also no diligence, which, according to our respondents, is characteristic of the first and last President of the USSR.

Our respondents consider sociability, activity, intelligence (the quality erudite, which was also present in the list of descriptors, was not chosen), and simplicity to be typical for both Gorbachev and Yeltsin.

The features that distinguish Gorbachev as a politician and the head of the state are his egoism and resourcefulness, as concerns Yeltsin - ambition.

In general, it is noteworthy that the semantic universals that reflect the ideas of our respondents about the personal qualities of the last president of the USSR and the first president of Russia existing in their language consciousness contain an insignificant number of characteristics: out of 64 descriptors included in the semantic differential "Personal traits of a politician", only 24 are actualized in the group representation.

\section{Debates}

The content of the simulated semantic universals, as it seems, can be explained by several reasons.

First, one of the factors that influenced the results, and, accordingly, the content of ideas about the personalities of Mikhail Gorbachev and Boris Yeltsin in the language consciousness of the studied group, could be the lack of structured knowledge of history among the participants 
of the experiment. We mean not only knowledge about a certain period of the country's development and even its entire history, but the system of historical knowledge about the stages and trends of development of the whole world. The main task to be solved in the process of education is the formation of such a system, and only if it exists, the image of a politician's personality in the mass consciousness, primarily in the minds of schoolchildren and students, will be formed considering all the circumstances and characteristic of the situation in which they were evolved and then acted. Note that in our case this reason turns out to be significant, which is confirmed by the notes of our respondents, primarily future sociologists (and this is very symptomatic, taking into consideration their future profession), left in the questionnaires ("I don't know much", "I don't know", "I haven't heard much", "I can only partially evaluate", etc.). In other words, the data obtained in the experiment suggest that at the present stage the functions of educational discourse are gradually beginning to be performed by other source including mass media, and this fully correlates with the opinion expressed by a great number of foreign researchers.

On the other hand, in our opinion the current situation is a vivid illustration of the well-known thesis of A.N. Leontiev, who emphasized that in certain cases a person's judgments about the historical past are determined primarily by the ideological representations of society, when an individual, due to the lack of personal experiences, can only go by assimilating "ready-made" meanings from the outsideknowledge, concepts, views that he receives via communication, in various forms of individual or mass communication. This creates the possibility of introducing distorted or fantastic ideas into his consciousness, including those that have no basis in his real, practical life experience. ... turning into stereotypes, they, like any stereotypes, are capable of resistance. ... But their destruction does not yet lead to the disintegration of consciousness, its inadequacy, it only creates its devastation, that can turn into a psychological catastrophe" (Leontiev, 2004: 119) (italics of the author - I. B., E. T.). Accordingly, the very risk of such a catastrophe (at the individual level or on a national scale) is directly related to the activities of various social institutions that offer an individual a choice, and "this is not a choice between values, but between colliding social positions that are expressed and realized through these values" (ibid.: 119). 
It can be expected that in this situation the marker of the existing today if not a catastrophe then a noticeable "confusion" of consciousness in the younger generation are precisely the significant discrepancies in the assessments of the personal qualities of M.S. Gorbachev and B.N. Yeltsin given by our subjects: a significant part of the answers obtained during the experiment tended to polar estimates, which ultimately affected the number of descriptors included in the indent ranges. Especially indicative in this respect was the descriptor saboteur. Here as in all cases of choosing extreme values for other qualities of the evaluated stimulus we can assume the dependence of the respondent's opinion on their choice in a situation of collision of opinions of official mass media and the immediate environment or assessments given by alternative sources of information.

And, finally, it is impossible not to note the contribution to the creation of uncertainty and even the disintegration of consciousness due to the peculiarities of the presentation of material about Mikhail Gorbachev and Boris Yeltsin distinguishing most mass media, which cannot but affect the ideas of our respondents about the personal qualities of the politicians in question. It is known that trust especially in a situation of a conflict of opinions (and the assessment of the leaders' personalities of country as evidenced by many studies is still ambiguous), is caused by information provided by at least two sources, and both interlocutors (authors) show the subject of discussion from several sides giving different arguments in defense of their point of view (Mayweg-Paus \& Jucks, 2018; Hendriks \& Jucks, 2020). In the current context as the analysis of articles published for anniversaries has shown this principle is almost never observed. As a result, some part of the audience accepts the broadcast opinions without a deliberate choice, which makes us recall the remark of $\mathrm{Zh}$. Baudrillard (Baudrillard, 2020) about the "least common culture", a classic situation of information "consumption" for modern society. The other, on the contrary, denies everything even rational arguments, and this second part is much larger in number because the qualities of kindness, care for the country and the people, wisdom, etc. emphasized in mass media were not reflected in the results obtained and, consequently, they are absent in the group representation of the last leader of the USSR and the first President of Russia in the language consciousness of humanities students. 
In general, the obtained experimental data demonstrate that the group assessment of the personal qualities of politicians whose actions had a huge impact on the further development of Russia does not always coincide with their language characteristics, which dominate the media, particularly political discourse. And in this case it can be argued with a high degree of confidence that the applied strategies and tactics of influencing mass consciousness, which are an integral part of both political discourse and media discourse as a whole, are not effective enough. That is why the activities of mass media currently lead not to the formation of a shared view on their history by a significant part of young people, but, on the contrary, to the maintaining of distinctions and, consequently, the preservation of socio-political contradictions, the existence of which is noted today by leading domestic sociologists (Levashov, 2018).

\section{The findings}

Thus, summing up the conducted pilot study in brief, which is (and this should be emphasized once again) only part of the planned work, it should be noted that the experimentally identified group ideas of modern students about the personal qualities of Mikhail Gorbachev and Boris Yeltsin that exist in their language consciousness are rather blurry, "kaleidoscopic" in nature, which, in our opinion, is due to two important reasons related to mass media directly or indirectly.

Firstly, due to the active and, moreover, very aggressive policy of modern mass media, the digitalization of modern society and the habits of information consumers that have already been formed, mass media and Internet platforms are actively constructing the perception of various events of the past in the mass consciousness, gradually replacing the educational discourse that is losing to them in terms of the impact on the consciousness of young people.

Secondly, as the data obtained show, modern mass media despite their rather advantageous position currently play a rather destructive role in creating a common view of Russian history and the qualities of its recent leaders. The result might lead to a state of psychological conflict in the society directly related to culture and the human "self", with "identification confusion" (E. Erickson's term), which has the function of collective ego. 
Summing up the above, we emphasize that the conclusions made are only preliminary. However, in our opinion, the study of the specifics of language consciousness, the content of which reflects the peculiarities of the perception of Russian leaders by young people who influenced the course of the historical development of not only our country but also the whole world, as well as the role of various information channels and the effectiveness of their strategies and tactics in the formation of images of these people, seems to be a very promising area of research within the framework of applied psycholinguistics, primarily in the aspect of the theory of speech influence on the content of language consciousness.

\section{Appendix 1}

\section{Semantic differential "Personal qualities"}

Please evaluate your idea of the politician you have proposed. Circle the number (from the series 0123), which, in your opinion, most accurately determines the degree of severity of this quality in this person, provided that 0 is not expressed; 1 - weakly expressed; 2 - medium expressed; 3 - strongly expressed.

добрый
спокойный
общительный
замкнутый
честный
пассивный
активный
умный
лицемерный
открытый
глупый
сильный
простой
организованный
эгоистичный
самокритичный
трудолюбивый
опытный
самодовольный
подлый
твердый
грубый
скромный
тревожный
нахальный
рассеянный
обаятельный
вспыльчивый
скованный
доброжелательный
гибкий
неуверенный

$\begin{array}{lllll}\text { тактичный } & 0 & 1 & 2 & 3 \\ \text { расчетливый } & 0 & 1 & 2 & 3 \\ \text { безвольный } & 0 & 1 & 2 & 3 \\ \text { ограниченный } & 0 & 1 & 2 & 3 \\ \text { безалаберный } & 0 & 1 & 2 & 3 \\ \text { оптимист } & 0 & 1 & 2 & 3 \\ \text { тонкий } & 0 & 1 & 2 & 3 \\ \text { холодный } & 0 & 1 & 2 & 3 \\ \text { мечтательный } & 0 & 1 & 2 & 3 \\ \text { неопытный } & 0 & 1 & 2 & 3 \\ \text { естественный } & 0 & 1 & 2 & 3 \\ \text { подвижный } & 0 & 1 & 2 & 3 \\ \text { остроумный } & 0 & 1 & 2 & 3 \\ \text { эрудированный } & 0 & 1 & 2 & 3 \\ \text { недоброжелательный } & 0 & 1 & 2 & 3 \\ \text { беспечный } & 0 & 1 & 2 & 3 \\ \text { изворотливый } & 0 & 1 & 2 & 3 \\ \text { творческий } & 0 & 1 & 2 & 3 \\ \text { корыстолюбивый } & 0 & 1 & 2 & 3 \\ \text { отходчивый } & 0 & 1 & 2 & 3 \\ \text { честолюбивый } & 0 & 1 & 2 & 3 \\ \text { неприятный } & 0 & 1 & 2 & 3 \\ \text { посредственность } & 0 & 1 & 2 & 3 \\ \text { мелочный } & 0 & 1 & 2 & 3 \\ \text { изнеженный } & 0 & 1 & 2 & 3 \\ \text { красивый } & 0 & 1 & 2 & 3 \\ \text { знающий } & 0 & 1 & 2 & 3 \\ \text { закомплексованный } & 0 & 1 & 2 & 3 \\ \text { упорный } & 0 & 1 & 2 & 3 \\ \text { праздный } & 0 & 1 & 2 & 3 \\ \text { поэтичный } & 0 & 1 & 2 & 3 \\ \text { вредитель } & 0 & 1 & 2 & 3 \\ \text { вани } & & & \end{array}$


Personal Qualities of M.S. Gorbachev and B.N. Yeltsin in Language...

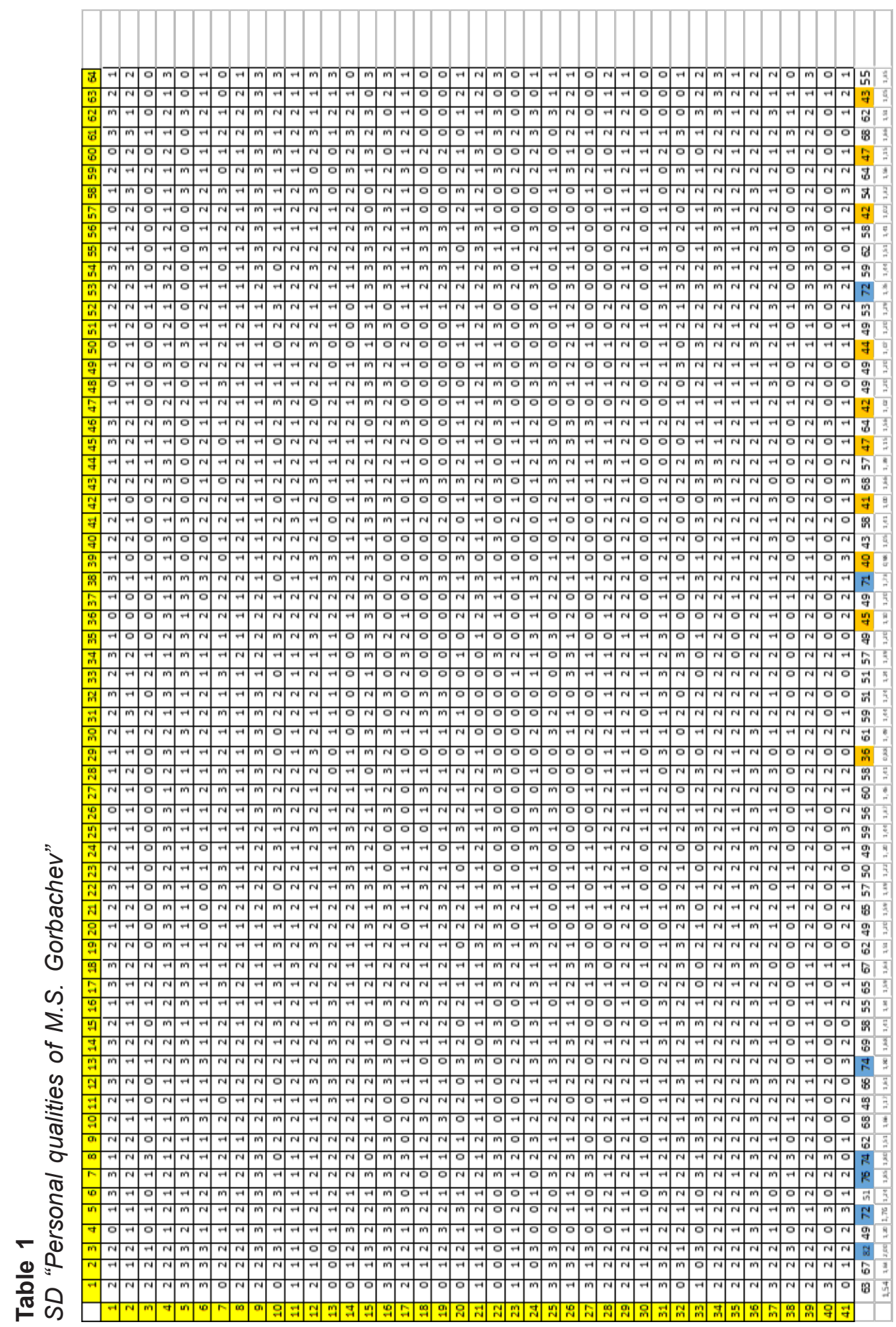


Особистісні якості М.С. Горбачова і Б.М. Сльцина у свідомості...

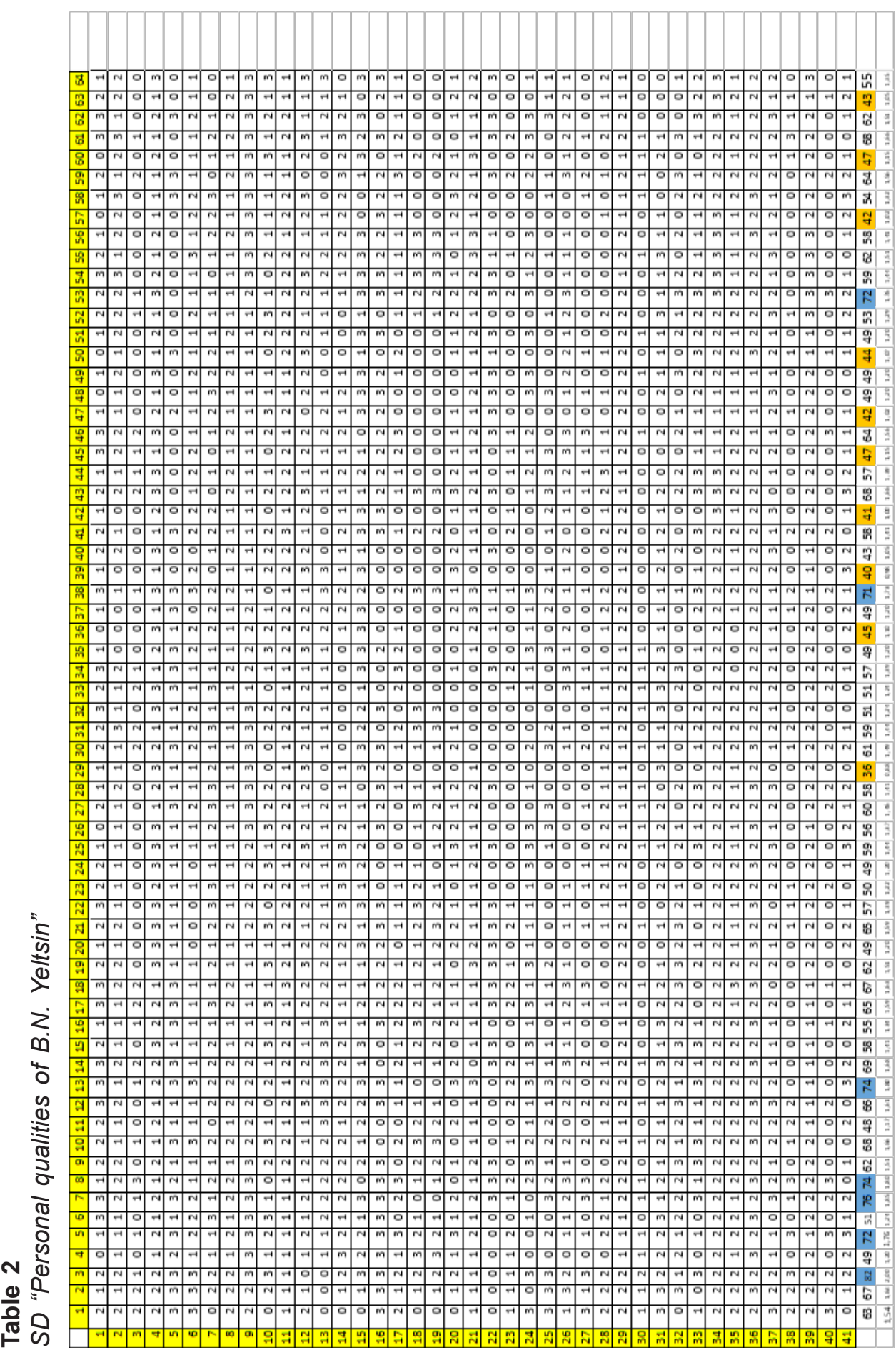




\section{References}

Artemyeva, E.Yu. (1999). Osnovy psihologii subektivnoj semantiki [Fundamentals of the Psychology of Subjective Semantics]. In I.B. Khaninoy (Ed.). Moscow: Nauka; Smysl [in Russian].

Bail, C.A. et al. (2018). Exposure to opposing views on social media can increase political polarization. Pnas, 115(37), 9216-9221. https://doi.org/10.1073/ pnas. 1804840115

Baudrillard, J. (2020). Obshhestvo potreblenija [Consumer Society]. Moscow : Izd-vo AST [in Russian].

Bernays, E. (2010). Propaganda [Propaganda]. In I. Yushchenko (Trans.). Moscow : Hippo Publishing [in Russian].

Blank, G., \& Lutz, C. (2017). Representativeness of social media in Great Britain : Investigating Facebook, LinkedIn, Twitter, Pinterest, Google+, and Instagram. American Behavioral Scientist, 61, 741-756. https://doi. org/10.1177/0002764217717559

Bubnova, I. (2021). Personal Qualities of the Leaders of Russia of the XXth Century (June 12, 2021). Available at SSRN: https://ssrn.com/abstract=3865736

Gruzd, A., Jacobson, J., \& Wellman, B. (2017). Social Media and Society: Introduction to the Special Issue. American Behavioral Scientist, 61(7), 647-652. https://doi. org $/ 10.1177 / 0002764217717567$

Gruzd, A., Jacobson, J., Wellman, B., \& Mai, P.H. (2016). Understanding communities in an age of social media: The good, the bad, and the complicated. Information, Communication \& Society, 19(9), 1187-1193. https://doi.org/10.1080/136911 8X.2016.1187195

Gruzd, A., \& Wellman, B. (2014). Networked influence in social media: Introduction to the special issue. American Behavioral Scientist, 58(10), 1251-1259. https:// doi.org/10.1177/0002764214527087

Harvey, D. (2007). Neoliberalism as Creative Destruction. The Annals of the American Academy of Political and Social Science, 610(1), 21-44. https://doi. org/10.1177/0002716206296780

Hendriks, F., \& Jucks, R. (2020). Does Scientific Uncertainty in News Articles Affect Readers' Trust and Decision-Making? Media and Communication, 8(2), 401. https://doi.org/10.17645/mac.v8i2.2824

Kolomiets, V.P. (2017). Sociologija massovoj kommunikacii v obshhestve kommunikacionnogo izobilija [Sociology of Mass Communication in a Society of Communication Abundance]. Sociologicheskie issledovanija - Sociological research, 6, 3-14. https://doi.org/10.7868/S0132162517060010 [in Russian].

Leontiev, A.A. (1969). Jazyk, rech, rechevaja dejatelnost [Language, speech, speech]. Moscow : Prosveshhenie [in Russian].

Leontiev, A.A. (1972). K psihologii rechevogo vozdejstvija [To the psychology of speech impact]. Proceedings from TSAPE' 72: Vsesojuznyj simpozium po psiholingvistike $i$ teorii kommunikacii - The All-Union Symposium on Psycholinguistics and Communication Theory (Moscow, 1972) (pp. 28-41). Moscow : Akademija nauk SSSR. Institut jazykoznanija [in Russian].

Leontiev, A.A. (1983). Jazyk propagandy : socialno-psihologicheskij aspekt [The language of propaganda : socio-psychological aspect]. Jazyk kak sredstvo ideologicheskogo vozdejstvija - Language as a means of ideological influence (pp. 15-33). Moscow : Inion AN SSSR [in Russian]. 
Leontiev, A.N. (2004). Deiatelity. Soznaniye. Lichnost [Activity. Consciousness. Personality]. Moscow : Smysl; Academy [in Russian].

Levashov, V.K. (2018). Novye socialno-politicheskie protivorechija na puti dostizhenija ustojchivogo razvitija [New socio-political contradictions on the way to achieving sustainable development]. Sociologicheskie issledovanija - Sociological research, 12, 107-119. https://doi.org/10.31857/S013216250003174-4 [in Russian].

Lippman, W. (1966). Public Opinion. N.Y.

Mayweg-Paus, E., \& Jucks, R. (2018). Conflicting Evidence or Conflicting Opinions? Two-Sided Expert Discussions Contribute to Experts' Trustworthiness. Journal of Language and Social Psychology, 37(2), 203-223. https://doi. org/10.1177/0261927X17716102

Ming Liu (2017). "Contesting the Cynicism of Neoliberalism": A Corpus-Assisted Discourse Study of Press Representations of the Sino-US Currency Dispute. Journal of Language and Politics, 16(2), 242-263. https://doi 10.1075/jlp.15010.1i

McLuhan, G. (2018). Ponimanie media. Vneshniye rasshirenia cheloveka [Understanding Media. External extensions of man]. Moscow : Kuchkovo pole [in Russian].

Serkin, V.P. (2008). Metody psihologii subektivnoj semantiki $i$ psihosemantiki [Psychology methods of subjective semantics and psychosemantics]. Moscow : Izd-vo PCHELA [in Russian].

Serr, M. (2016). Devochka s palchik [Girl with a finger]. Moscow : Ad Marginem Press [in Russian].

Shmelev, A.G., Pokhilko, V.I., \& Kozlovskaya-Telnova, A.Yu. (1988). Praktikum po jeksperimentalnoj psihosemantike (tezaurus lichnostnyh chert) [Workshop on Experimental Psychosemantics (Traits Thesaurus)]. Moscow: Izd-vo Mosk. un-ta [in Russian].

Vygotsky, L.S. (2004). Psihologija razvitija cheloveka [Psychology of human development]. Moscow: Izd-vo Smysl; Izd-vo Eksmo [in Russian].

\section{Internet resources}

VCIOM: dolja rossijan, negativno ocenivajushhih dejatelnost Gorbacheva, snizilas [VTSIOM: the share of Russians who negatively assess Gorbachev's activities has decreased]. Retrieved from https://tass.ru/obschestvo/10815565

Opros: Gorbachev dumal o blage strany, no sovershal takticheskie proschety [Poll: Gorbachev thought about the good of the country, but made tactical mistakes]. Retrieved from https://rg.ru/2021/03/02/opros-gorbachev-dumal-oblage-strany-no-sovershal-takticheskie-proschety.html

Put ot tanka do groba. Istorija Borisa Elcina $v$ fotografijah $-k$ ego 90-letiju [The path from tank to coffin. The story of Boris Yeltsin in photographs - to his $90^{\text {th }}$ birthday]. Retrieved from https://360tv.ru/news/tekst/borisu-eltsinu-90/

"Chelovek s sobstvennym mneniem". Vyskazyvanija o Mihaile Gorbacheve ["A man with his own opinion”. Statements about Mikhail Gorbachev]. Retrieved from https://tass.ru/info/10807011 
Personal Qualities of M.S. Gorbachev and B.N. Yeltsin in Language...

\title{
Бубнова Ирина \& Токарева Елена. Личные качества М.С. Горбачева и Б.Н. Ельцина в сознании студентов-гуманитариев
}

\begin{abstract}
АННОТАЦИЯ
Вступление. Цель исследования - выявление и описание фрагмента языкового сознания студентов-гуманитариев, отражающего их представления - личностных качествах М.С. Горбачева и Б.Н. Ельцина; в качестве дополнительных ставились такие задачи: (1) сравнение выделенных экспериментально характеристик с качествами, оказывающимися в фокусе официальных СМК; (2) анализ роли медийного дискурса в формировании образов исследуемых политиков.
\end{abstract}

Методы исследования. Методом униполярного личностного семантического дирфреренциала, относящегося к специализированным предметноотнесенным, выделялись наиболее характерные и отсутствующие качества исследуемых стимулов. Обработка результатов включала в себя выявление групповых универсалий оценки, их качественный анализ, сравнение и качественный анализ сходств и различий полученных универсалий оценки исследуемых стимулов. Тексты СМК, опубликованные к 90-летию Горбачева и 90-летию Ельцина, выделенные методом случайной (серийной) выборки, анализировались качественно.

Результаты. Групповые семантические универсалии, отражающие представления студентов об исследуемых политиках, бедны по содержанию. Наиболее яркой характеристикой Горбачева является эгоизм и изворотливость, в отличие от Ельцина его представляют опытным, трудолюбивым и спокойным. Ельцина, по мнению респондентов, выделяло честолюбие. Оба руководителя предстают как свободные в своем поведении, различия заключаются в том, что Горбачева считают опытным, но лишенным такта и гибкости, у Ельцина отсутствует творческое начало, остроумие и недоброжелательность. Объединяют данных руководителей такие черты как общительность, активность и ум. В эксперименте не зафиксированы те качества, на которых акцентируется в публикациях СМК - доброта и забота о благе страны.

Выводы. Представления современных студентов о личных качествах М.С. Горбачева и Б.Н. Ельцина носят достаточно размытый, "мозаичный" характер. Несмотря на активность массмедиа, конструирующих их образы в массовом сознании, групповая оценка личных характеристик данных политиков не совпадает с интерпретацией, предлагаемой различными СМК, чья деятельность в целом не способствует выработке разделяемого значительной частью общества взгляда на свою историю, что, в свою очередь, ведет к консервации социально-политических противоречий в обществе. Более того, несмотря на весьма выгодную позицию, современные массмедиа играют, скорее, деструктивную роль в создании общего взгляда на историю России и качества ее недавних руководителей. Результатом этого может явиться состояние психологического конфликта в обществе, непосредственно 
связанного с культурой и человеческим " $Я$ ", с "идентификационной спутанностью” (термин Э. Эриксона), имеющей функцию коллективного эго.

Ключевые слова: семантический дифреренциал, семантические универсалии, личностные качества, руководители, Россия, студенты, СМк.

\section{Бубнова Ірина \& Токарева Олена. Особистісні якості М.С. Горбачова i Б.М. Єльцина у свідомості студентів-гуманітаріїв}

АНОТАЦІЯ

Вступ. Мета дослідження - виявлення й опис фрагмента мовної свідомості студентів-гуманітаріїв, котра відображає їхні уявлення про особистісні якості М.С. Горбачова і Б.М. Єльцина; в якості додаткових ставилися такі завдання: (1) порівняння експериментально виокремлених характеристик із якостями, котрі опиняються в фокусі офіційних ЗМК; (2) аналіз ролі медійного дискурсу у формуванні образів досліджуваних політиків.

Методи дослідження. Методом уніполярного особистісного семантичного диреренціала, який відноситься до спеціалізованих предметно-віднесених, виокремлювалися найбільш характерні й відсутні якості досліджуваних стимулів. Обробка результатів включала в себе виявлення групових універсалій оцінки, їх якісний аналіз, порівняння та якісний аналіз подібностей та відмінностей отриманих універсалій оцінки досліджуваних стимулів. Тексти ЗМК, опубліковані до 90-річчя Горбачова і 90-річчя Єльчина, виокремлені методом випадкової (серійної) вибірки, аналізувалися якісно.

Результати. Групові семантичні універсалії, котрі відображають уявлення студентів про досліджуваних політиків, бідні за змістом. Найбільш яскравою характеристикою Горбачова є егоїзм і спритність, на відміну від Єльцина його представляють досвідченим, працьовитим і спокійним. Єльцина, на думку респондентів, вирізняло честолюбство. Обидва керівники постають як вільні у своїй поведінці, відмінності полягають у тому, що Горбачова вважають досвідченим, але позбавленим такту і гнучкості, у Єльцина відсутнє творче начало, гострий розум і недоброзичливість. Об'єднують цих керівників такі риси, як товариськість, активність і розум. В експерименті не зафіксовані ті якості, на яких акцентується в публікаціях зМК - доброта і турбота про благо країни.

Висновки. Уявлення сучасних студентів про особистісні якості М.С. Горбачова і Б.М. Єльцина носять досить розмитий, "мозаїчний" характер. Незважаючи на активність мас-медіа, які конструюють їхні образи в масовій свідомості, групова оцінка особистісних характеристик цих політиків не збігається з інтерпретацією, запропонованою різними ЗМК, чия діяльність у цілому не сприяє виробленню в значної частини суспільства одностайного погляду на свою історію, що, в свою чергу, призводить до консервації соціальнополітичних протиріч у суспільстві. Більше того, незважаючи на досить вигідну позицію, сучасні мас-медіа відіграють, швидше, деструктивну роль у створенні 
Personal Qualities of M.S. Gorbachev and B.N. Yeltsin in Language...

загального погляду на історію Росії та якості ї̈ нещодавніх керівників. Результатом цього може бути стан психологічного конфлікту в суспільстві, безпосередньо пов'язаного з культурою та людським "я", з “ідентифікаційною плутаниною” (термін Е. Еріксона), котра має функцію колективного его.

Ключові слова: семантичний диференціал, семантичні універсалії, особистісні якості, керівники, Росія, студенти, ЗМк. 